\title{
The Creation of the Albanian State and its Relationship with Religious Communities: The Sanctioning of Religious Plurality as a Condition of National Unity
}

\section{Erjon Papagjoni}

Jurist, Tirana, Albania

Doi: 10.1515/ajis-2017-0026

\begin{abstract}
Abrstact
The Albanian state sanctioned after the Lushnja Congress in 1920 applied a liberal and wise policy to religious communities, aiming to create ethnic, social and national cohesion among the people through the recognition of the plurality of religious beliefs, their mutual respect, of correct relations with the state and the strengthening of national unity, according to the advanced conventions of modern European states. The new Albanian state committed itself to recognizing all the rights of religious communities in Albania so that they would normally practice their religious activity with all rituals and prayers according to their faith, dogmas, and sacred canons, enhancing spiritual influence in people. To provide legal support to four main religious communities - Muslim, Bektashi, Orthodox, and Catholic - the state sought the design and approval of the correspondent statutes of each religious community. The new political situation required that the new statutes include the need for the independence of religious communities from the type of their former legal structures and reports that they had under the Ottoman Empire. On the other hand, the Albanian state openly proclaimed its secular character in relation to religions. In the statutes of the four main religious communities, with their peculiarities, were included the rights and obligations to believers, the way of organizing hierarchy and clerical forums, the correct legal relations with the state, which ensured and guaranteed their normal functioning, education religious programs, schools at their various ranks, staff and administration, their wealth, their administration and publications, in order to realize the spiritual impacts and the educational power that religion aims to offers to the masses of believers (Albanian Encyclopaedia Dictionary, 2009).
\end{abstract}

Keywords: statute, religious community, religion, legal, state.

\section{Brief Historical Overview}

Through centuries, at times under the jurisdiction of the Roman Church (Western) and other times under the jurisdiction of the Byzantine Church (Eastern), Albanians were divided into two religious communities originating from the same skeleton: Christianity. The arrival of the Ottoman Empire also brought the conversion of some of them to the Muslim religion, sometimes with force and legal constraints and other times voluntarily for reasons of interests and favors. During the famous reform called Tanzimati (1839-1876) initiated under the imperial decision of Hatif-serif, known as the "Rose Garden Edict", the problem of equality among citizens with respect to the law, despite the religious beliefs they had, was highlighted (Maksudoglu, Mehmet, 2017). In the Albanian territories, this reform recognized and imposed the organization and existence of four milets: the Muslim Sunni 
milet, that of Bektashi Milet, the Christian Orthodox Milet and the Catholic Milet. ${ }^{1}$ An important decision of the Ottoman Empire, which created a favorable climate for the expression and affirmation of the religious affiliation of the citizens, took place in the year 1856, called Hatt's Humayun. The above decision removed the obstacles to the practice of religions in the various milets of the Ottoman Empire by not allowing the forced conversion of Christian populations into Muslim populations. Patriarchs, metropolitans, archbishops and bishops, representing the believers who were under their jurisdiction, benefited salaries and were forced to swear in front of the sultan and the state, offering guarantees of loyalty, in order to enforce the agreements.

This structure of different religious identities in Albania, known and legalized by the Ottoman Empire in four milets, highlighted the issue about the character and the specificity of the construction and formation of the Albanian state of tomorrow when the empire would collapse and his official religion could no longer be Islamic. A major step was taken when Mustafal Qemal Pasha, known as Ataturk, took power and became the designer of a new Turkey with a secularist tendency to separate the state from religion. (N. H. Thirlwall, 1993). All this process, sublimated in the historical synthesis that had already created the necessary premises and precedents, ran into Albania the idea of national unity, elaborated by the national Renaissance, which will be realised through the slogan "Albanian religion is the Albanism." This meant that their next state could not be established and functioned through religious separatism, rather it was to be designed on religious tolerance to ensure the necessary inter-Albanian cohesion of all religious clusters.

\section{The Legal Prerogatives of the New Albanian State in Relation to Religion}

Alongside the main role of religious communities as institutions that assure the exercise of faith in their own milet-es in accordance with all their canons, rules, dogmas and scriptures, concurrently they also perform a political role without harming their core and key functions. This feature has and continues to have an impressive originality in the Albanian population in the lands where they live, reflecting an exemplary human positivity and solidarity. On the other hand, the country's elite understood instinctively that the new Albanian state, which was expected to rise, could not function politically as the supreme authority of power and the major actor in the interaction of society's social, economic and moral components, without the reconciliation and the spirit of compromise between different social identities created during the Ottoman Empire in the form of milet, so of the main religious communities. That is why their representation in the high dome of the state as a governing chain was considered a vital condition and obligation.

Since the first government of Ismail Qemali, the structure and composition of the cabinet became an expression of the political participation of their representatives, but it took full legal form precisely in the design and construction of the Albanian state after the Lushnja Congress, which was held on 21 January 1920. In Article 1, Part A, which defines the character of the state and its functions, followed in Articles 45-68, the Narta Council was defined as the highest state organ, elected by the Parliament with a three-year mandate. Four of the top religious representatives of the country were summoned in its composition. From the Catholic community was elected bishop, Mr. Luigj Bumçi, from the Bektashi community was elected Aqif Pasha Elbasani (Aqif Biçakçiu), from the Muslim community was elected Abdi Toptani and from the Orthodox community his grace, bishop dr. Mihal Turtulli. This was a collegial body in equality reports, which thus respected the very religious structure of the country. The High Council was adopted on January 31, 1920 with the corresponding amendments to the "Statute of Lushnja", otherwise known as the Basics of the Kanun of the High Council.

Its four members, from the four respective religious communities, composed an organ functioning through a well-defined formula including rotation, and were each elected in a quarterly

\footnotetext{
${ }^{1}$ Religious communities represented defined organizations of the population under the jurisdiction of the Ottoman Empire, which were otherwise called Milet. Christian, Orthodox and Catholic communities, unlike the Muslim community, signed an agreement with the Ottoman state for their protection, otherwise called dhimma, which obliged them to pay a reward in favor of the Empire and the Sultan.
} 
term as chairman of this Council. In this way, to guarantee as much cohesion, respect and harmony as possible, the leadership of the new Albanian state was originally of a collegial character. Naturally, the structure, the interior, the composition of the new Albanian parliament implied the contributions of all religious communities and their participation through a formula of correct and well-meaning representation.

Since its creation, the Albanian state, had a "peculiar" existence, conditioned primarily by the plurality of different religions that Albanians had embraced in the course of time, finding themselves in the outset of the 20th Century, with at least four religious communities: Muslim, Bektashi, Orthodox, and Catholic. Unlike many other nations, which their state had as a premise and element of union and social cohesion a unique and cohesive religion, on the contrary, the Albanian population divided into four major religious groups, as well as in fraternity and other sects of small affiliations. This reality demanded, as a prerequisite for the existence and functioning of the state, precisely the acceptance of religious plurality, and therefore the need for coexistence and solidarity between them, especially on vital national issues. It appeared since the genesis, as a fundamental requirement about the conception of the state and its structuring (Luarasi, Alex, 1999)

\section{Institutional Form of Religions and Its Legal Justification}

Since 1923, the decree-law on religious communities explicitly emphasized that "Every branch of Muslim religion such as Sindhi, Bektashism, Rufaism, Halvetism, Kadirism, and others, and any branch of Christendom, such as Catholicism, Orthodoxy, Protestantism as well as all branches of any other religion, can be organized into independent religious societies." (http/licodu.cois.it/412/view)

This legal extract that had a very advanced approaching for the circumstances that form the setting conditions of Albania in the early 1920s, after its secession from all the legal cover of the Ottoman Empire regarding the state's relations with religion, undoubtedly, expressed a liberal concept of attitude moderator. It consisted of accepting and guaranteeing the plurality of beliefs, even within its statutory legal space. The above formulation on plurality of faith offered a conscious acceptance of the importance and space of every religion aiming to guarantee and promote among all believers, coexistence and understanding.

This religious plurality articulated in the legal point of view expressed in the founding statute of the state and the relevant articles created the premise and conditions necessary for finding a conifer of all Albanian society. On the one hand, he was, in a sense, a "living modus" of the spiritual interests and situations of the various social fragments according to the religion they exerted and, on the other hand was the state, as the bearer of the will of such measures, as the harmonizer and the advocate of the interests social and political, as the instrument of creating national cohesion in the construction of fair legal relationships with religious communities separately and in general. Thus, religious communities, in the immanent relationship with the state, should have all the chances of representation in the organs, forums, and constituent parts thereof: legislative, executive, and justice. This status quo became a prerequisite for the good functioning of the Albanian state in its beginnings, while subsequent secularization would also effect the natural separation of the state from religion. (http://www.statoechiese.it/images/uploads/articoli_pdf/cimbalo_i_rapportim2.pdf)

The new Albanian state had to sublimate the best, most reasonable and productive part of the experiences gained from the Ottoman Empire period following Tanzimati's reform about religious communities. But furthermore, he was tasked with learning and embracing the experience of European countries with their secularism, parliamentarism and functional democracy, their respect for religion and the right to belive, preserving harmony and strengthening solidarity between communities religious as a prerequisite for the provision and preservation of social cohesion and national unity. (E. A. Sewell, 2010)

Thus, the relationship between the new Albanian state and religion, at its core, implied the promotion and building of an exemplary social equilibrium, based precisely on guaranteeing peace, harmony and religious understanding of the population. This enabled the achievement of social cohesion and the exhaustion and decline of religion- based conflicts that could undermine the country's political stability. 


\section{An Experience Not Only "Albanian"}

It is interesting to note that the formula found since the project of the Lushnja Congress for the construction and operation of the state offered a very advanced solution and concept for the time related to the state's relation with religion and religious entities. This concept, though taking into account the country's canons and Montesquieu's well-known theory of secularism in the democratic state, was still legally uncharted even in the other European countries with the most advanced legal experience of the relationship with the religion $(\mathrm{N}$. H. Thirlwall, 1993). Albania offered a complex reality about the coexistence of the four religious communities within the legal satete framework which ever since its inception, proved a clear secular tendency and religious tolerance.

The relationship between the new Albanian state and religions, in its political essence, meant promoting and building an exemplary social equilibrium, based precisely on guaranteeing peace, harmony and religious understanding of the population. This created the possibility to achieve the social cohesion and the suppression of conflicts that undermined the country's political stability. On the other hand, in order to give guarantees for the independence of the new Albanian state from political claims or influences against the territorial integrity of the country, the "Statute of the Albanian State" of 1922 emphasized that the relations of religious institutions with their homologous in different countries in the world would have only "spiritual bonds, dogmas and sacred canons". On the contrary, no dependence that could undermine this independence and integrity, would be allowed. (http/licodu.cois.it/415/view) At the same time, for the fulfillment and the guarantee of this condition it was foreseen that the clergy of religious communities were Albanian nationals up to three generations and performed rituals in Albanian, except when the majority of the population in a given geographic region or entity spoke in other languages (for example, the area of the Greek minority in southern Albania). (http/licodu.cois.it/415/view) In this case, religion should not be used as a political pretext to pursue non-religious purposes, especially regarding territorial claims against the Albanian State, as was the case of the "Republic of Vorio Epirus" (Morozzo della Rocca, R., 1999).

Albanian Bektashians had a range of differences with the Sunni Muslim community. As a religious community following the religious practices of the Sufi sect, in a generally liberal and not rigid way, Bektashi believers pray twice a day, not five times as Sunnis. Prayers do not necessarily direct their faces towards Mecca; do not sit on their knees and do not put their heads on the ground. Also alcoholic beverages were not prohibited, women participate in religious rituals in teqe, unlike sunnies who do not allow men and women together during prayer. The Bektashis do not have a month of fasting and do not necessarily hold Ramadan (AQSH. Fondi nr. 882).

The statute of the Albanian Muslim community of the Sunni sect has a contemporary conception and even reformative approach of many of the codes once brought by Shaykh-ul-Islam. Among others, there are some such as: a) opposition to religious orders related to the humiliating position of a woman, such as the prohibition of polygamy and the marriage of some women, b) the prohibition of suits or vests covering their faces, c) rejection of the believer's landing on the ground during prayer with the body and the face turned upside down (Zani i Naltë, 1935).

Another feature of this Statute was the liberal and democratic character regarding the handling of property and material goods available to religious communities. It must be asserted that thus it provided an advanced and modern legal concept for the time. The state did not become a possessor of property and inheritable assets of religious institutions, as well as of all profitable accounts provided by legal sources, charities, gifts and other publicly known and honest activities. This was an exclusive right legally sanctioned by the state for these communities, concerning their governing and administrative forums that proceeded in economic and financial terms. The State, on the contrary, exercised only control and revision of the revenues identified according to the instructions and powers recognized by law, in particular the use of material goods by the clergy. In fact, this legal optics was rejected by the Catholic and Orthodox communities, while the two Muslim communities, the Sunni and the Bektash, accepted it.

The need to draft the statutes of four religious communities to legitimize and regulate the new legal relations with the state was considered a national political imperative. Their legal and civil personality was first expressed in the 1922 constitution, also called the Extended Lushnja Statute 
(Albanian Encyclopaedia Dictionary, 2009).

Concerning the above, Giovanni Cimbalo rightly emphasizes the idea pointed out also in our studies that, with the drafting and adoption of the statutes of religious communities as the legal structure for regulating the relationship of religion with the state "Albania becomes the only country in Europe who drafts the norms for granting legal personality to religious communities, which represents the most progressive rate of European law processing, demonstrating its ability to embed the essence of constructive debate so necessary for the establishment of the modern state."

\section{Conclusions}

- Since its creation, the Albanian state has considered religion and religious communities as factors of social and national cohesion. He followed the principle of plurality of beliefs and equal respect for them.

- The statutes of the four main religious communities in Albania - the Muslim, Orthodox, Catholic and Bektashi - established the legal basis of state relations with religion and religious communities.

- The separation of the state from religion was the founding act of the Albanian state that dismissed the inheritance of the East and brought them closer to the legislation of democratic states in Western Europe.

- Secularism became the new feature of Albanian society.

- Religious communities disconnect their ties from world respective centers addiction, except Catholics.

- The state turned into a supporter of the activity of religious communities in accordance with this correct legal relationship.

\section{References}

A. B. Tomorri (1994), History of Bektashism, Wisdom, no. 3, Tirana.

Academy of Sciences of the Republic of Albania, Orthodox Autocephalous Albanian Church (1993), Symposium - Tirana, 19 September 1992, Tirana.

Albanian Encyclopaedia Dictionary (2009). New Edition, Third Volume: N-Zh and a Supplement, Tirana (pp. 1239-1242 \& 1179-182): Academy of Sciences, Albanian Encyclopaedia Center.

AQSH. Fondi nr. 882, 1923, dosja 4, f. 8.

Cimbaldo, Giovanni (2013). Religious Pluralism and Religious Communities in Albania, Studies of Comparative Law. Christian rights and human rights. Religion Report with State in Albania (pp. 43), Tirana: Naimi.

D. Sadikaj (1972), Position of Religion in Albania under the Conditions of the Communist System (pp. 34), Tirana.

E. A. Sewell (2004), Law and Religion in Positive Europe (pp. 212-243), Bologna.

E. A. Sewell (2010). Religious Freedom in Central and Eastern Europe. Human Rights and Religious Freedom, (edited by Vittorio Possenti): Rubettino, Soveria Mannelli (pp. 117).

G. Barberini (2010). Pages of Contemporary History. The Holy See at the Helsinki Conference, Cantagalli Editore Siena.

Luaras, Alex (1999). Legal Acts on the History of State and Law in Albania (pp. 29-57), Tirana: SHBLU.

Maksudoglu, Mehmet (2017). Historia osmane dhe institucionet (Ribotim i rishikuar 2017), Hapja e territoreve ndaj Islamit në Shqipëri (pp. 175-178 \& 474)), Tiranë: ALSAR

Morozzo della Rocca, R. (1999), Nazione e religion in Albania. (pp. 44-62), Bologna: II Mulino.

N. H. Thirlwall (1993). Islam in the Balkans, Religion and the Society Between Europ and the Arab World: Hartus \& C. London.

R. Kaliçani (1999), Histori e bektashizmit si sekt mistik mysliman, (pp. 62), Tiranë: Koha.

Retrievedfrom:http://www.statoechiese.it/images/uploads/articoli_pdf/cimbalo_lalbaniam.pdf

Retrieved from: $\mathrm{http} / /$ Licodu. Cois. it / 412 / view

Retrieved from: https://sq.wikipedia.org/wiki/Bektashizmi

Retrieved from: Statuti legal $i$ komuniteteve fetare, http/licodu.cois.it/415/view

S. Hysi (2000), Muslimism in Albania 1945-1950, Tirana: First Teacher.

A. Dalipaj (1992), Albanian State Relationships with the Orthodox Church (pp. 36-37), Tirana.

D. Sadikaj (1972). The Position of Religion in Albania under the Conditions of the Communist System (pp. 504), Tirana. 
Mr. Simoni (1998), Persecution of the Catholic Church in Albania 1944-1990 (pp. 271-273), Shkodër. Zani i Naltë (1935), nr. 4, (pp. 399-410): Shkodra. 